\title{
袖壁つき $\mathrm{RC}$ 造柱の最大耐力以降の挙動の評価法 \\ - EVALUATING METHOD OF POST PEAK BEHAVIOR OF R/C COLUMNS WITH SIDE WALLS
}

\author{
加藤大介*, 孫 浩 陽** \\ Daisuke KATO and Hao Yang SUN
}

\begin{abstract}
The objectives of this study were to propose a simplified method to evaluate load defection relationship of reinforced concrete columns with side walls which could be used in the practical design procedure. The flexural and shear behaviors of columns was discussed separately and the load deflection relationship of columns was evaluated according to their failure mode. The design equation for shear strength proposed by AIJ (Design 'guidelines for earthquake resistant reinforced concrete buildings based on inelastic displacement concept) was applied with some modification to evaluate shear behavior of columns with irregular section. Characterized points such as flexural cracking point, yielding point, losing point of design lateral load carrying capacity and losing point of design axial load carrying capacity were considered in the flexural behavior.
\end{abstract}

Keywords : column with side walls, shear strength, flexural strength, deformation capacity, axial load carrying capacity 袖壁つき柱, せん断強度, 曲げ強度, 変形能, 軸力負担能力岥失点

\section{1. はじめに}

\section{1 研究の背景}

1968 年の十勝沖地震においては、袖壁, 腰壁あるいは垂壁が建 物の耐震性能に悪い影響を及ぼすことが明らかになった。すなわち、 袖壁等が付いた部材そのものが脆性的な破壊性状を示すこと、およ び、袖壁等に直交してとりつく部材の可撓長さが短くなることによ りその部材がせん断破壊しやすくなることである。

これらを背景に袖壁等が取り付く部材の静加力実験が行われ [1 〜 等]、曲げ強度やせん断強度の設計式が提案されてきた。提案 式は、例えば、日本建築センターの建築物の構造規定 [6]に示さ れており、現在、設計で多用されている。しかしながら、その一方 で、鞓性能に富んだ梁降伏形建物を実現するために，それ以降袖壁 等が極力排除されてきた傾向もある。

1995 年の阪神大震災では, 逆に, 袖壁等を取り払った純フレー ムの損傷が大きくなり，修復が困難になるという欠点が露出した。 純フレームの損傷が大きくなるのは設計で意図しているところであ るが, 今後耐震設計法が性能評価型設計法に移行していったときに, 終局限界性能だけではなく, 使用限界性能や修復限界性能を向上さ せることも必要となってくる。袖壁, 垂壁, 腰壁等は, 使用性能や 修復性能を高めるために有効であり，今後その举動を精度良く評価 する手法の開発が重要になってくる。

これらを背景に、袖壁付の部材の研究が新たに行われるように なった [7〜9 等]。大宮らは、異形断面を長方形断面に置換するこ となく、曲げ強度を連続的に評価できる設計式を提案している $[7]$ 。
また、せん断強度の評価法としては、阪神大震災以降注目されてい る連続䋞維補強に関連させたものが多く、益尾ら [8]、磯ら [9] の研究がある。磯らは、異形断面を長方形断面に置換して終局強度 型設計法 [10］に示されたせん断強度式を適用する方法を提案し ている [9]。

\section{2 研究の目的}

筆者らは、整形断面の柱部材を対象に、帯筋による拘束効果を 取り入れた変形能や軸力負担性能等の最大耐力以降の举動の評価法 の研究を行ってきた $[11,12]$ 。さらに、これらの成果を異形断面柱 に適用することを目的とし、 R C 造異形断面柱の面内加力実験を行 った [13]。終局状態に至るまでの举動を、曲げとせん断力による 影響を分離して評価することを目的としており、そのため、軸力を パラメータとし、袖壁部分に閉鎖型せん断補強筋を用いた試験体と なっている。本論文では、この実験及び既往の諸実験結果を元に、 設計で使用できる程度に简略な袖壁付柱の荷重一変形関倸の評価法 を提案することを目的とした。最大耐力以降の举動の評価に重点を 置いており、曲げ举動は前述したように帯筋による拘束効果を取り 入れた整形柱用の変形能や軸力負担性能の評価式を異形断面に適用 することを、せん断举動は勒性保証型設計法 [14] で提案されてい る带筋による拘束効果を取り入れた整形柱用のせん断強度を異形断 面に適用することを試みた。

\section{3 本諭文の概要}

荷重一変形関係は曲げ挙動とせん断挙動に分離してそれぞれ評 価し、ある変形において、曲げ抵抗荷重とせん断抵抗荷重の小さい
* 新潟大学工学部建設学科 教授・丁博

** 新潟大学自然科学研究科博士課程前期 大学院生
Prof., Dept. of Architecture, Faculty of Engineering, Niigata University, Dr. Eng. Graduate Student, Dept. of Architecture, Faculty of Engineering, Niigata University 
值をその異形断面の荷重とした。

曲げ挙動であるが、袖壁を有する柱の特徵は、早期に袖壁部分 が圧壊し、強度が急激に低下するが、その後柱断面が曲げに抵抗し、 安定した举動を示すところにある。そこで、本論文では、この異形 断面の特性を表現するために、異形断面を袖壁断面のみと柱断面の みの 2 つにモデル化し、曲げひび割れ点、降伏点、降伏強度品失点、 軸力負担能力啔失点をそれぞれ評価し、その包絡線を曲げによる荷 重一変形関倸とした。

一方、せん断強度式としては、勒性保証型設計法を異形断面に 適用する方法（提案式）を検討した。せん断挙動による荷重一変形 関係は、コンクリート強度の有効係数 $v$ を変化させたときのせん断 強度と Ry+Rp の関保とした。なお、せん断強度については、比 較のために、既往のせん断強度式の適用法（長方形断面置換）、長 方形断面に置換して終局強度型設計法を適用する方法、異形断面と して終局強度型設計法を適用する方法、についても検討した。

評価式の精度の検証には、既往の実験結果（文献 $[1 \sim 5,8,13]$ ) を用いた。本提案ではせん断破壊するまでの荷重一変形関倸は曲げ 変形のみを考慮していることになる。ところが、袖壁長さが長くな ってくると、せん断変形の影響が無視できなくなると考えられる。 そこで、袖壁長さの適用範囲としては、奏験データで検討した範囲、 すなわち、袖壁長さが柱幅の 2 倍程度（左右計で 4 倍）と考えてい る。

\section{2. せん断力に対する挙動の評画法}

\section{1 既往のせん断強度式の啇用法（長方形断面置換）}

まず、設計や診断で多用されている異形断面用のせん断強度式と して、日本建築センターの建築物の構造規定 [6] の式について検 討した。これは長方形断面に対する実験式を異形断面用に修正した ものであり、本論文では構造規定式と呼ぶ。

\section{2 長方形断面に置換して终局強度型設計法を適用する方法}

構造規定式では変形能を直接評価することはできないが、変形能 まで評価できるせん断強度式としては日本建筑学会の終局強度型耐 震設計指針 [10］に示されているトラス機構とアーチ機構に基づ いた式がある（終局強度型による式と呼ぶ）。ただし、この式は異 形断面に対応していないので、本論文では、図 1 に示すように、異 形断面を柱と袖壁に置換して適用し、その大きい方を異形断面のせ ん断強度とした。なお、図に示すように、壁筋が柱型を貫通してい る場合は柱置換モデルのせん断補強筋に壁筋を含め、貫通していな い場合には含めない。

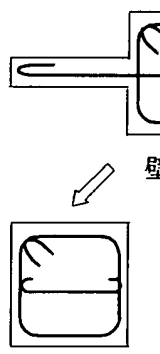

柱置換モデル

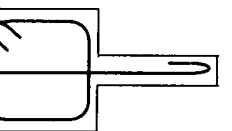

壁筋貫通
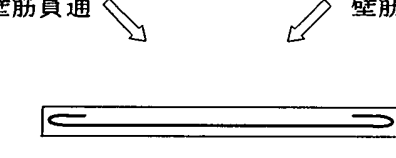

袖壁置換モデル

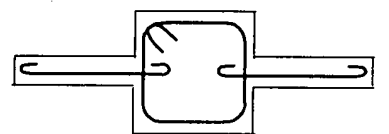

壁筋非貫通

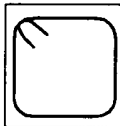

柱置換モデル

図 1 整形断面に置換する場合（終局強度型設計法によるせ ん断強度式を使用) の柱置換モデルと袖壁置換モデル

実験值を用いた式の精度に関する検討は後述するが、ここでは柱 置換モデルと袖壁置換モデルのモデル化による差異をみておく。図 2 (a)は後述する試験体を対象に柱置換モデルと袖壁置換モデルに よるせん断強度を比較したものである。いずれも最大強度の実験值 で基準化してある。袖壁置換した方がやや大きい強度を与えること が多いことが分かる。図 2 (b)は横軸に両側の袖壁長さの和を柱幅 で除したものをとり、縦軸に袖壁置換モデルのせん断強度に対する 柱置換モデルのせん断強度の比をとったものであるが、袖壁が短い 場合には柱置換モデルの方が大きくなる傾向になる。

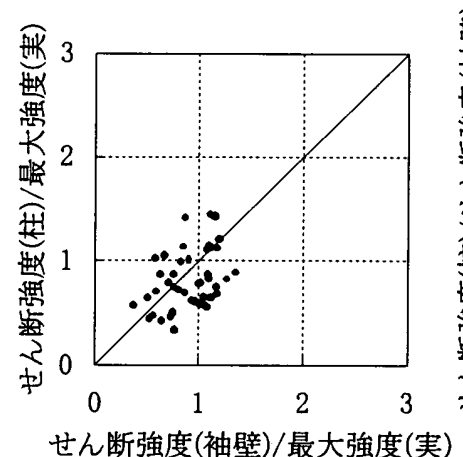

(a) せん断強度の比較

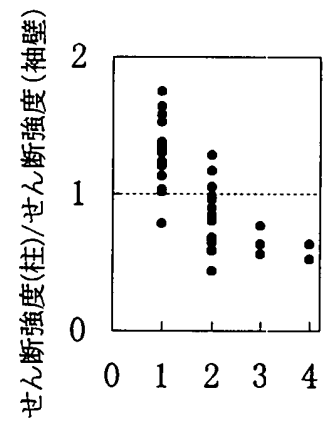

袖壁長さの和/柱幅

(b) 袖壁長さの影響
図 2 整形断面に置換する場合（終局強度型設計法によるせん断 強度式を使用）の柱置換モデルと袖壁置換モデルの強度の比較

一方、終局強度型による式を用いた場合の曲げ降伏後の変形能 は、塑性回転角 Rp がコンクリート強度の有効保数 $v$ と関連づけら れているので、曲げ強度とせん断強度が一致するところの Rp とし て求まる（変形能としては降伏変形を加えた $\mathrm{Ry}+\mathrm{Rp}$ )。

2.3 異形断面として終局強度型設計法を適用する方法

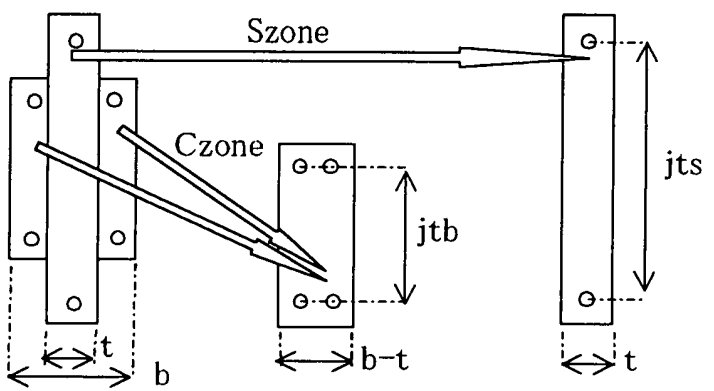

(a)トラス機構

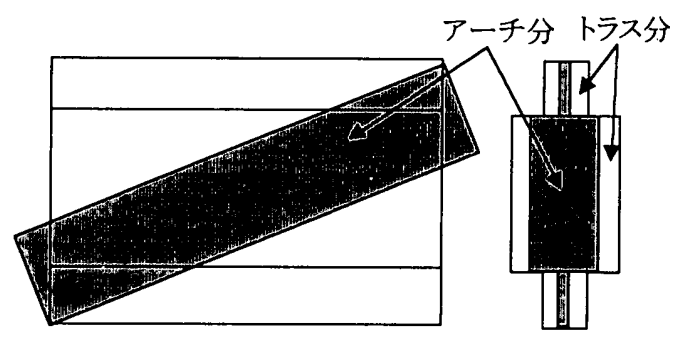

(b) アーチ機構

図 3 終局強度型設計法を用いて異形断面としてせん断強度 式を評価するモデル 
日本建築学会の終局強度型設計耐震指針［10］を直接異形断面 に適用することを試みる。図 3 はその適用法を示したものであるが、 図 3(a)に示すようにトラス機構は袖壁部分（Szone）とその残り の柱部分 (Czone) に分割してそれぞれ求める。Szone とC zone のトラス機構の強度の和が異形断面のトラス負担分となる。一方、 トラス機構で使われたコンクリートを除いた部分がアーチ機構で使 われるコンクリートとなり、図 3 (b) の塗りつぶし部分がそれにあ たる。このアーチに有効な断面は一般的に異形断面となるが、アー チの角度が与えられれば、そのアーチ束の最小断面よりアーチ負担 分が与えられる。

実際の計算は、トラス機構とアーチ機構の角度を変化させて、収 束計算により求められた最大值が異形断面のせん断強度となる。

\section{4 異形断面として勒性保証型設計法を道用する方法（提案式）}

異形断面柱の特徵は帯筋により十分に拘束される柱型部分と拘束 の程度が低い袖壁部分で構成されるところにある。例えば袖壁のせ ん断補強筋がシングル配筋の場合は拘束効果は0であり、たとえ閉 鎖型のせん断補強筋で拘束されていても、壁厚が柱幅より相当薄い ことを考えると、その拘束効果は柱部分に比べかなり弱くなる。従 って、異形断面柱のせん断抵抗機構を評価する際には、拘束効果の モデル化が重要となる。そこで、本論文では、拘束効果を考慮しう るせん断強度式として勒性保証型耐震設計指針に示された方法をと りあげ、この手法を異形断面に拡張して用いることを試みる。

日本建築学会の勒性保証型耐震設計指針 [14] では、横補強筋 によるコアコンクリートの拘束効果を考慮し、終局強度型によるせ ん断強度式を修正した式が提案されている（勒性保証型による式と 呼ぶ)。この式は、アーチ機構に対しては全断面が有効であるが、 トラス機構に対しては閉鎖型横補強筋により囲まれたコアコンクリ ートのうち有効に拘束される部分のみが有効と考えるところに特徴 がある。有効に拘束される部分のコアコンクリートに対する面積比 （入）は、帯筋間隔（s）が小ざくなるほど、あるいは、中子筋の 数が増えるほど 1 （全断面拘束を意味する）に近くなるように式(1) で与えられている。

$$
\lambda=(1-\mathrm{s} / 2 \mathrm{je}) \cdot(1-\mathrm{bs} / 4 \mathrm{j} e)
$$

ここで、 j e は断面のトラス機構に対する有効せい、bs は断面の トラス機構に対する有効幅（be e ）を中子筇の本数 +1 で除したも の（中子筋を含めた横補強筋同士の間隔に相当）、である。（詳しく は文献 [14］を参照)

次ぎに、このせん断強度式の異形断面への適用法について示す。 無拘束コンクリートはトラス機構には寄与できない。そこで、トラ ス機構に関しては横補強筋に拘束されている柱型断面のみを対象に 靭性保証型と同様に評価する。ただし、袖壁付き柱断面の有効拘束 面積比入s は、図 4 に示すように、袖壁のとりつく部分は有勃に拘 束されるとし、袖壁のつく部分とつかない部分を平均化した式(2) により.評価する。

$$
\lambda \mathrm{s}=\mathrm{t} / \mathrm{be}+\lambda \cdot(\mathrm{be}-\mathrm{t}) / \mathrm{be}
$$

ここで、入は袖壁のとりついていない部分のみの有効拘束比で、式 (1)により求める。このときのb s は、簡略化のためbs 1 と b s の 大きい方とするが（図 4 参照）、中子筋の存在により柱単独のb s がそれよりも小さくなるときは柱単独のbsとしてよい。

次に、アーチ機構は横補強筋による拘束は不要なので、アーチ機
構が存在する場合には、そのせいは袖壁を含めた全せいD（図 4 参 照）で評価する。ただし、その幅は袖壁厚さ $\mathrm{t}$ を限とする。

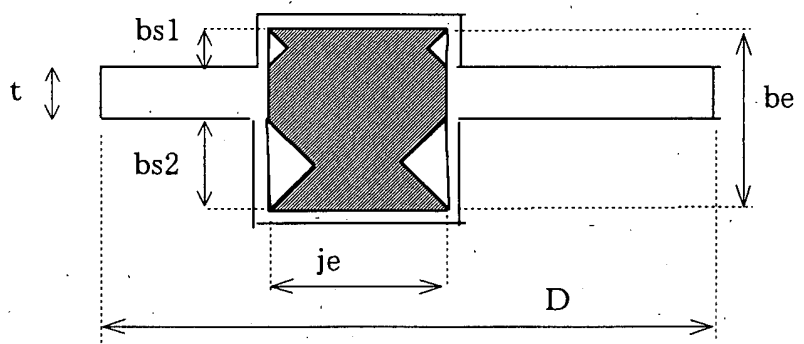

$\mathrm{bs}=\min (\max (\mathrm{bs} 1, \mathrm{bs} 2)$, 柱単独のbs)

図 4 勒性保証型設計法を用いて異形断面としてせん断強度 式を評価する場合（せん断強度提案式）の異形断面モデルの 記号と拘束領域

以上が異形断面への適用法であるが、柱型に比べて袖壁断面が 大きい場合には、袖壁断面だけのせん断強度が前述の異形断面強度 より高くなる場合があるので、図 5 に示すように、異形断面モデル と袖壁置換モデルに分離して評価し、その大きい方をせん断強度と する。この際、袖壁置換モデルも勒性保証型によるせん断強度式を 適用するが、袖壁の壁筋が単筋の場合には、トラス機構は期待せず、 アーチ機構のみとする。図6(a)(b)は異形断面モデルと袖壁置換モ デルのせん断強度の関係を見たものであるが、ほとんどのケースで 異形断面モデルによる強度が高い。袖壁置換モデルの方が異形断面 モデルより大きい場合もあるが、これは袖壁が長い場合や袖壁の配 筋が複筋になっている場合である。

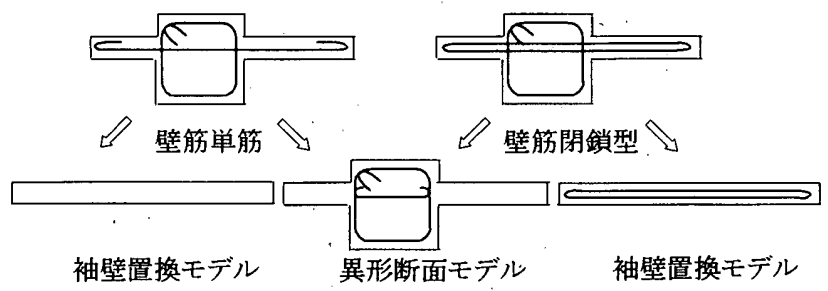

図 5 勒性保証型設計法のせん断強度式を適用する場合（せん 断強度提案式) の異形断面モデルと袖壁置換モデルへの置換法

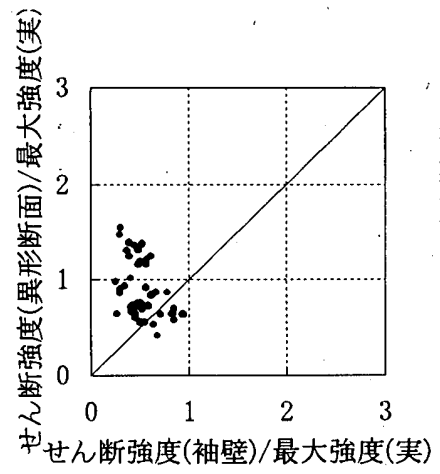

(a) 強度の比較

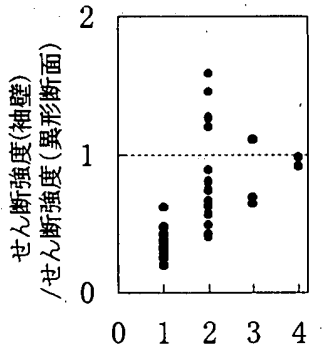

袖壁長さの和/柱幅 (b) 袖壁長さの影響
図 6 勒性保証型設計法のせん断強度式を適用する場合（せん断 強度提案式）の異形断面モデルと袖壁置換モデルの強度の比較 
図 7 は勒性保証型設計法のせん断強度式を適用する場合のトラス 機構の負担割合をみたものである。図 (a) は横軸に柱型のみの帯筋 比をとっているが、帯筋比が低いところで一部アーチ機構の負担が 大きいところがあるが、多くの試験体はトラス機構が支配的だと分 かる。また図(b)は部材角を横軸にとった例であるが、 $\mathrm{R} p \mathrm{p}$ が小さ いところで、アーチ機構が存在していても、部材角が大きくなると トラス機構のみにより負担されていることがわかる。

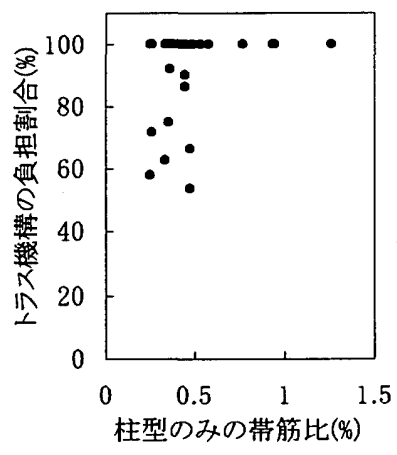

（a）带筋比とせん断強度に対

するトラス機構の負担割合

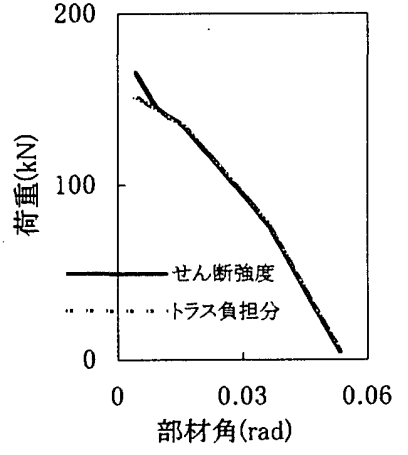

(b) 部材角とせん断強度の関
図 7 勒性保証型設計法のせん断強度式を適用する 場合（せん断強度提案式）のトラス機構の負担割合

\section{3. 曲げ挙動の評田法（提案式）}

\section{1 考え方}

前述したように、袖壁を有する柱の曲げ挙動の特徵は、早期に袖 壁部分が圧壊し、強度が急激に低下するが、その後柱断面が曲げに 抵抗し、安定した挙動を示すところにある。袖壁が圧壊するところ だけを取り出すと、変形能にそしい部材と評価せざるをえないが、 軸力保持性能等を考えると柱単独断面程度の性能は示す。従って、 異形断面の特性を表現するために、以下のモデル化を試みる。すな わち、図8に示すように、異形断面を袖壁断面のみと柱断面のみの

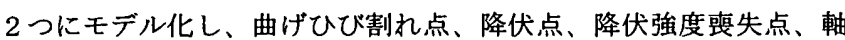
力負担能力喪失点をそれぞれ評価し、その包絡線を曲げによる举動 とする。

袖壁モデルは柱型を無視したもので、柱モデルは圧縮側袖壁を無 視し、引っ張り側の袖壁を包絡する長方形断面に㯰換したものであ る。いずれのモデルも引張に有効な全軸方向筋（a t ）を重心位置 に集約し、軸力 $(\mathrm{N})$ は柱型のあった場所の中心位置に作用させる。

\section{2 曲げ降伏強度の詳画法}

いずれのモデルも長方形断面なので、曲げ降伏点までは、一般的 な方法で求められる。ここでは、降伏変形は菅野式 [15］を用い、 曲げ強度は式(3)によった。

$\mathrm{My}=0.9 \mathrm{at} \cdot \sigma \mathrm{y} \cdot \mathrm{D} \cdot \mathrm{g}+\gamma \cdot \mathrm{N} \cdot \mathrm{D}\left(1-\mathrm{N}\left(\mathrm{b} \cdot \mathrm{D} \cdot \sigma_{\mathrm{B}}\right)\right)$

(3)

ここで、記号は図 8 に示した。また、 $\sigma \mathrm{y} 、 \sigma_{\mathrm{B}}$ は実強度とした。

図 9 (a)(b) は柱モデルと袖壁モデルの曲げ強度の関係を見たもの であるが、全てのケースで袖壁モデルによる強度が高かった。

\section{3 変形能の評任法}

鞋性保証型耐震設計法では、曲げ降伏強度を保てなくなる部材角
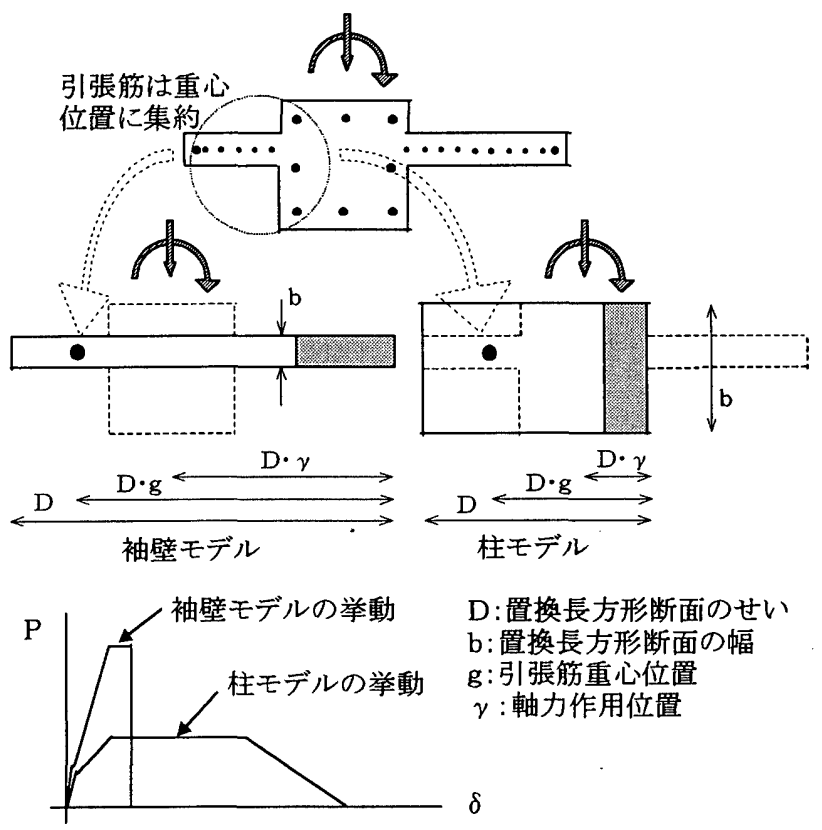

図 8 異形断面の曲げ抵抗モデル（曲げ強度提案式）

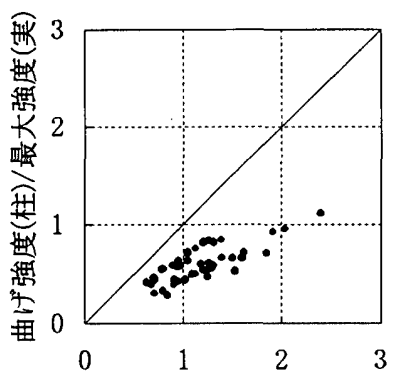

曲げ強度(袖壁)/最大強度(実)

(a) 強度の比較

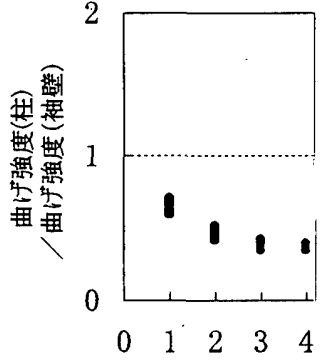

袖壁曼さの和/柱韽 袖壁モデルと柱モデルの強度の比較

Rf として、式(4)が示されている。

$$
\begin{aligned}
\mathrm{Rf}=\mathrm{Ry} & +\phi \mathrm{u} \cdot \mathrm{D} \\
\phi \mathrm{u} & = \begin{cases}(\mathrm{m} \cdot \varepsilon \mathrm{p} / \mathrm{je}) \cdot(2 / 3) / \mathrm{e} \eta & (\alpha \mathrm{ee}\langle<\mathrm{l} / 3) \\
(\mathrm{m} \cdot \varepsilon \mathrm{p} / \mathrm{je}) \cdot(2 / 3) /(5 \mathrm{e} \eta-4 / 3) & (1 / 3<\mathrm{e} \eta<2 / 3)\end{cases}
\end{aligned}
$$

ここで、e $\eta$ はコアコンクリートのみの等価軸力比で横補強筋によ る拘束効果を考慮して求める（等価軸力を $\sigma \mathrm{p} \times コ ア$ 断面積で除し たもの、詳細は文献 [14] 参照)。 $\sigma \mathrm{p} 、 \varepsilon \mathrm{p}$ は拘束コンクリートの 最大応力度およびその時の軸歪度である。式(4)はコンクリートを ストレスブロックに置換して平面保持を仮定した曲げ解析により定 式化されたものであるが、係数 $\mathrm{m}$ はストレスブロックの最大䄳度を 表す指標である。鞆性保証型設計法では、安全側（20\%下限）に評 価する值として実験的に得られた $\mathrm{m}=1.9$ が報告されている。

本論文では曲げモデルの降伏強度を維持できなくなる点を式(4) で評価した。ただし、柱モデルのコア断面はかぶり厚さが実在する 柱型と同じと仮定して求めた。また、 $\sigma \mathrm{p}$ と $\varepsilon \mathbf{p}$ は実在する柱型を 対象にして、New R Cプロジェクトの成果によるモデル [16] を 用いて評価した。この New R Cプロジェクトのモデルは、帯筋の 
詳細（中子筋の有無等）や間隔等の配筋法を考慮して、その拘束効 果を評価しうるモデルである。一方、袖壁モデルでは、一般に壁筋 が単筋であることが多いこと、および、複筋になっていても拘束効 果は大きくない（壁厚に比べて壁筋間隔が広い）ことを考慮して、 拘束効果は無視した。すなわち、全断面で軸力比を算出するかわり に、 $\varepsilon \mathrm{p}$ は無拘束コンクリートの值を用い、係数 $\mathrm{m}$ は 1 とした（m $=1$ は無拘束のコンクリートが最大応力度に達した後に急激に応力 度が低下することを意味している)。

次に、柱モデルの軸力負担能力若失点であるが、筆者らは、軸力 負担能力䨤失点も式(4)で評価を試みている [12]。これは最終的に 軸力負担能力を失う部材角を表す $\mathrm{m}$ を逆算したもので、平均的に評 価式として $\mathrm{m}=10$ が、20\%下限式としては $\mathrm{m}=4.4$ （耐力倸数 $\Psi$ =0.44）が報告されている。そこで、本研究では軸力負担能力喪失 点を安全側に評価する保数として $\mathrm{m}=4.4$ を用いた。

袖壁モデルの軸力負担能力歪失点であるが、無拘束コンクリー トは最大応力度に達するとただちに強度を失うとして、軸力負担能 力喪失点においても降伏強度を維持できなくなる点と同様に $\mathrm{m}=1$ とした。

\section{4. 評顷粘果}

\section{1 せん断強度と曲げ強度}

既往の実験結果（文献 $[1 \sim 5,8,13]$ ）を用いて、評価式の精度を 検討した。検討した試験体は計 45 体で、内 3 体が片側のみに袖壁 がとりつくものである（他は左右对称袖壁）。

图 10 にせん断強度式として構造規定式を適用した場合の、実験 值と計算値の比較を示す。嵲軸とも曲げ強度計算值で基準化してお り、図(a)が曲げ強度にも構造規定に示されている式を使った場合、 図(b)が式(3)を使った場合である。同様に、整形断面に置換した上 で終局強度型によるせん断强度式を適用したものを図 11(a)(b)に、 異形断面のままで終局強度型によるせん断強度式を適用したものを 図 12(a)(b)に、提案式である勒性評価型によるせん断強度式を適用 したものを図 13(a)(b)に示す。

せん断強度に構造規定式を用いたもの（図 10）は実験值を安全 側に評価しているが、実状に反してほとんどの試験体をせん断破壊 型と評価する結果となった。例えば、明らかに曲げ破壊と判断され る後述する図 16(b)の試験体 $4 \mathrm{~A} 205$ もせん断強度と曲げ強度の比 は 0.96 となり、せん断破壊と判断されている。なお、曲け破壊と 判定された試験体は片側のみに袖壁の付く 3 体のみであり、これは 構造規定式の曲げ強度が片側のみに袖壁が付く場合に過小評価する 傾向がある（引っ張り側の袖壁を完全に無視する）ためである。

終局強度型による場合は整形断面に置換した場合（図 11）は構 造規定式とほほ同程度の精度であったが、異形断面のままで適用し た場合（図 12）は危険側の結果となり、設計式としては適用でき ない。終局強度型を異形断面に適用する場合、袖壁部分と柱部分に 分離し、それぞれのせん断強度を算出しているが、この際、袖壁部 分にもトラス作用を期待している。本手法が過大評価になったとい うことは、袖壁部分には過度にトラス作用を期待できないことを意 味していると考えられる。

勒性保証型による場合（図 13）は、構造規定式に比べせん断強 度をより高く評価する傾向にあるが、その結果、実験值が計算值を

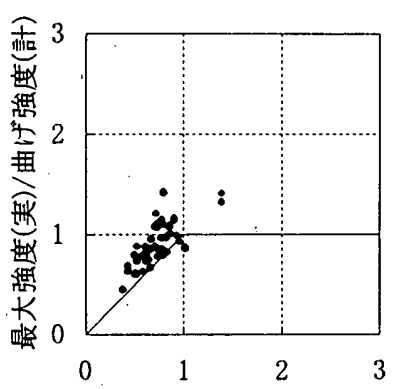

せん断強度(計)/曲げ強度(計)

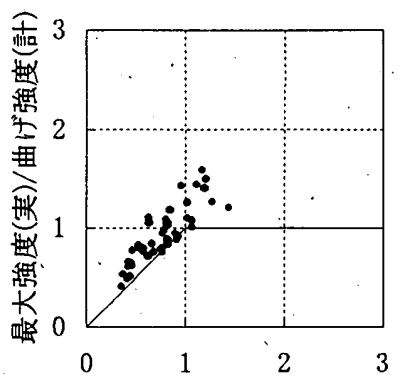

せん断強度(計)/曲げ強度(計)

(a) 曲げ強度に構造規定式を適用 （b）曲げ強度に提案式を適用

図 10 構造規定式によるせん断強度式を適用した場合の精度

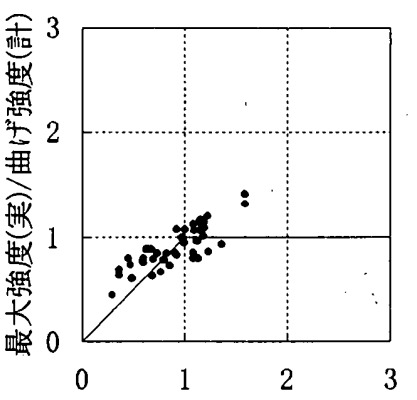

せん断強度(計)/曲げ強度(計)

(a) 曲げ強度に構造規定式を適用 図 11 整形断面に置換する場合 断強度式を使用）の精度

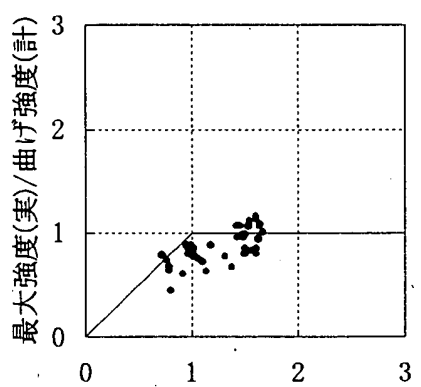

せん断強度(計)/曲げ強度(計) (a) 曲げ強度に構造規定式を適用 図12 終局強度型設計法を用いて を評価した場合の精度

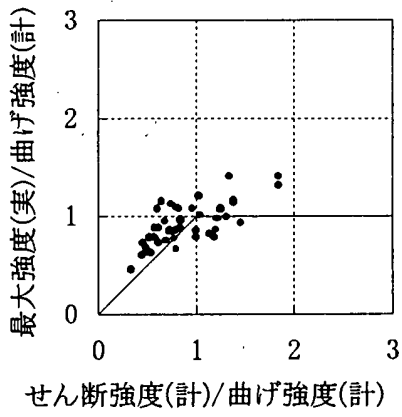

(a) 曲げ强度に構造規定式を適用

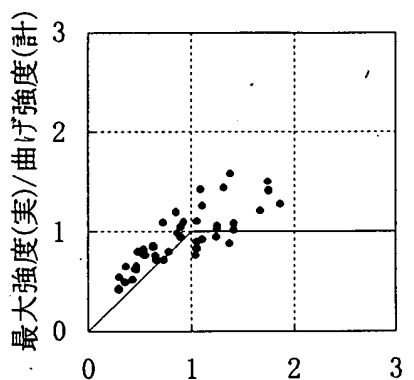

せん断強度(計)/曲げ強度(計)

(b) 曲げ強度に提案式を適用

図 13 勒性保証型設計法のせん断強度式を適用する場合（せん断 強度提案式）の精度 
下回るものも若干見られる。

曲げ強度に関して言えば（それぞれで図(a)(b)の比較）構造規定 式（図(a)）よりも提案式（図(b)）の方が若干低めの評価をしてい る。

\section{2 変形能（曲げ降伏強度表失点部村角）}

本節では、曲げ降伏強度梷失点として定義した変形能の実験值と 計算值を比較する。実験值は包絡線上で復元力が最大耐力の $80 \%$ 以下に低下するときの部材角とした。異形断面の場合はこの点は袖 壁部分の圧壊により決まるので、異形断面の挙動の中では変形能と 定義するにはふさわしくないと思われるが、従来の設計体系との連 続性を考えて評価しておく。

図 14 に、せん断強度式を用いた場合の、変形能の実験值と計算 值を比較する。図(a)が提案式である勒性保証型によるせん断强度 式、図(b)が整形断面として終局強度型を適用した場合である。曲 げによる変形能の影響も取り入れるために、図 15 では図 14 の両 軸を曲げにより決まる変形能（Rf）で除して示した。なお、曲げ による変形能とは袖壁モデルに式 $(4)(\mathrm{m}=1)$ を適用したものである。

結果はいずれも大きなばらつきが見られたが、終局強度型による 場合（図(b)）に比へ、鞄性保証型を用いた場合（図(a)）はほほ安 全側の評価となった。

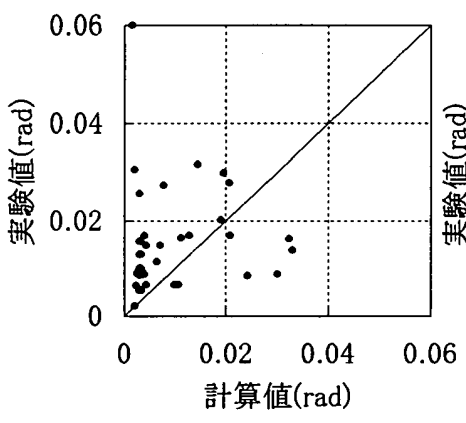

(a) 勒性保証型による変形能 (提案式)

図 14 従来型の変形能（最大強度の $80 \%$ に低下した部材角）を 対象にした場合のせん断強度式による変形能の評価精度

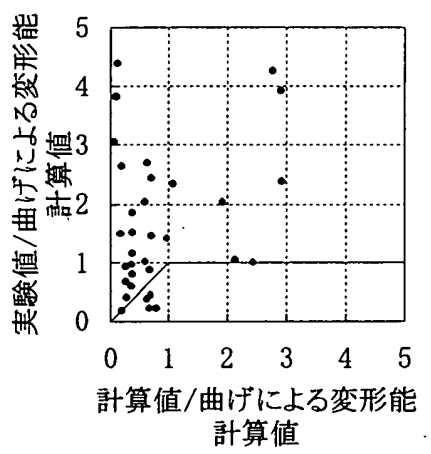

(a) 鞄性保証型による変形能 (提案式)

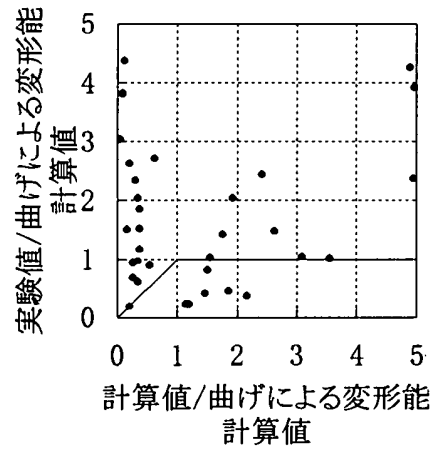

(b) 整形断面に置換した場合 (強度式は終局強度型設計法)
図 15 従来型の変形能（最大強度の $80 \%$ に低下した部材角）を 対象にした場合のせん断強度式による変形能の評価精度（曲げ による変形能で基準化した場合）

\section{3 荷重一変形関保}

前述したように、袖壁を有する柱はその挙動が複雑なので、荷重 一変形関倸をより現実的に評価することが重要である。本節では、 既往の実験結果の荷重一変形関倸と評価結果を比較した。曲げ举動 の計算值は図 8 に示した袖壁モデルと柱モデルの荷重一変形関倸の 包絡線（ある変形において大きい方の荷重）とする。せん断挙動の 計算值は勒性保証型による提案式を用い、コンクリート強度の有効 倸数 $v$ を変化させたときのせん断強度と $\mathrm{Ry}+\mathrm{Rp}$ の関你とした。 最終的な計算值は曲げ挙動とせん断举動の小さい方となる。

図 16、17 に荷重一変形関倸の実験值と計算値を比較して示す。 図 16(a)(b)の試験体は袖壁の配筋が単筋になっている場合で、前述 したように、曲げに抵抗する袖壁モデルに壁筋による拘束効果を考 慮していない。図(a)はせん断挙動が卓越する場合の例、図(b)は曲 げ举動が卓越する場合の例であるが、いずれも計算値は実験值を大 略評価している。

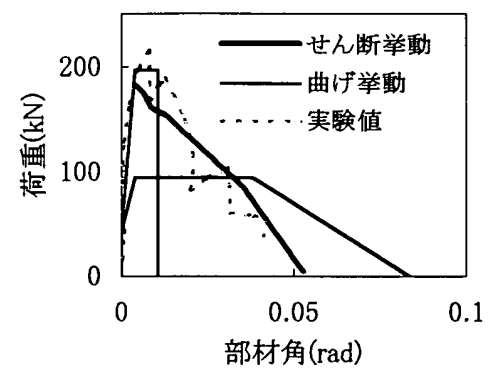

（a）せん断举動が卓越する例（試験体 CWNo. 6 [1]）

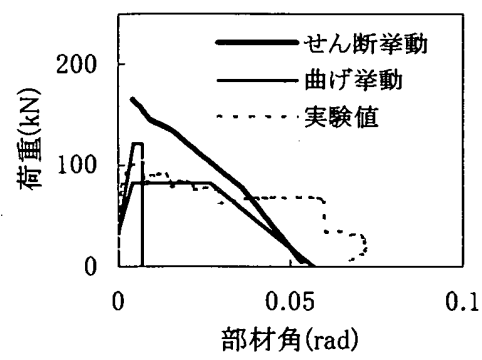

（b）曲げ挙動が卓越する例（試験体 4A205［3]）

図 16 荷重変形関倸の実験值との比較（袖壁が単筋の）場 合：曲げに抵抗する袖壁モデルに拘束を考慮していない)

図 17(a)(b)の試験体は袖壁の配筋が複筋になっている境合で、比 較的高軸力が作用している試験体である。特に、試験体 CSW-2（図 (b)）は軸力負担能力啔失点まで加力を行っているとこるに特徴が ある。3.3 節では、曲げに抵抗する袖壁モデルは袖壁が褀筋の場合 でも拘束の程度が低いために、無拘束コンクリートとして扱う（m ＝1）と述べたが、図 17 では、参考のために、曲げに捻抗する袖 壁モデルに拘束を考慮していない場合と考慮した場合（この場合は 袖壁に柱モデルを適用する）の両方を示した。結果をみると、いず れも計算值は実験值を大略評価しており、軸力負担能力融失点まで 加力した試験体 CSW-2（図(b)）の曲げ挙動の軸力負担能力茷失点 は実験值とよく一致している。袖壁モデルに壁筇の拘束効果を考慮 するかどうかという観点からは、拘束を考慮した方が実䮖值に近く はなったが、全体の挙動から見ると大差はなかった。 


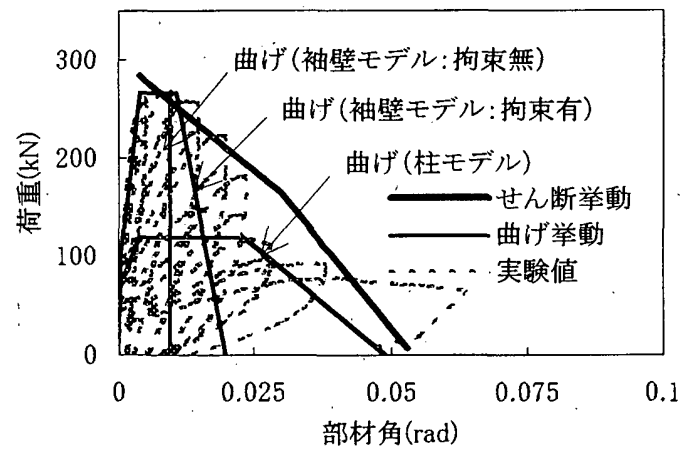

(a) 試験体 CSW-1 [13]

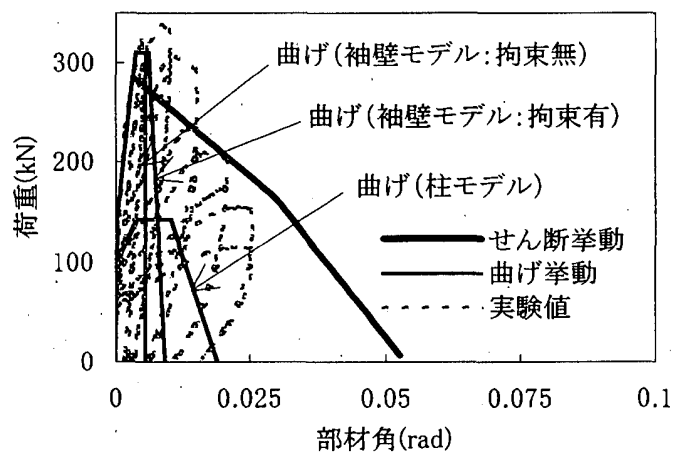

(b) 試験体 CSW-2 [13]

図 17 荷重変形関係の実験值との比較（袖壁が複筋の

場合：曲げに抵抗する袖壁モデルに拘束を考慮した場合 と考慮していない場合の両方を示した)

\section{5. まとめ}

(1)構造規定式によるせん断強度は実験值を安全側に評価したが、 ほとんどの試験体がせん断破壊型となった。

(2) 整形断面に置換して終局強度型を適用した場合は構造規定式と ほぼ同程度の精度であった。

（3）異形断面として終局強度型を適用した場合は、危険側の結果と なり、設計式としては適用できない。すなわち、袖壁部分には過度 にトラス機構を期待できない。

(4)提案したせん断強度式（勒性保証型）は、若干危険側となった データもあるが、ほぼ精度良く実験値を評価した。また、この式を 用いて変形能（曲げ降伏強度喪失点）も評価しうる。

（5）荷重一変形関倸の亭験値を計算値と比較した結果、せん断举動 が卓越する場合、曲げ举動が卓越する場合のいずれでも、計算値は 実験值を大略評価した。

謝辞本論文で用いた実験データは大谷裕美さん（元新潟大学 大学院、現（株）エスパス）作成によるものである。また、曲げ举 動解析に関しては望月広平氏（新潟大学学生）に多大な尽力をいた だいた。

\section{参考文南}

[1] 東洋一、大久保全陸：鉄筋コンクリート袖壁付き柱の逆対 称繰返し加力実験（その1：せん断補強の少ない場合）,日 本建築学会大会学術講演梗概集（東北）,pp.1405-1406, 1973

[2] 東洋一、大久保全陸、藤又康：鉄筋コンクリート袖壁付き
柱の逆対称繰返し加力実験（その 2 : 壁厚の異なる場合、 袖壁を付加して補強する場合), 日本建築学会大会学術講演 梗概集（北陸）,pp.1289-1290, 1974

[3］東洋一、大久保全陸 : 鉄筋コンクリート短柱の崩壊防止に 関する総合研究 (その9CWシリーズ : 袖壁付き柱の実験, 日本建築学会大会学術講演梗概集（北陸），pp.1305-1306, 1974

[4] 東洋一、大久保全、山本嘉孝、山根一博、磯健一：鉄笳コ ンクリート短柱の崩壊防止に関する総合研究（その37 C Wシリーズ：袖壁付き柱の第2次実験）,日本建築学会大会 学術講演梗概集 (東海), pp.1417-1418, 1976

[5］野村設郎、大森茂樹：RC造垂れ壁・袖壁・腰壁付柱の剛域 及び復元力特性, 日本建築学会大会学術講演梗概集（九州）, pp.1451-1452, 1981

[6] 日本建築センター: 建築物の構造規定, 1990

［7］大宮幸、林静男：袖壁付きRC柱の曲げ終局強度に関する考 察,日本建築学会構造系論文集,第542号、pp.155-162,2001.4

[8] 益尾潔、井上寿也、小林淳、服部明生 : 壁付き $\mathrm{RC}$ 柱の新し い耐震補強工法 (CFアンカー) の開発 その7 袖壁付き柱 の面内加力下の構造性能, 日本建築学会大会学術講演梗概集 （中国），pp.33,34, 1999

［9］磯雅人、松崎育弘、園部泰寿、中村洋行：連続瀻維シート によりせん断補强された袖壁付き RC柱のせん断終局耐力評 価,日本建築学会構造系論文集,第542号、pp.147-154, 2001.4

[10］ 日本建築学会：鉄筋コンクリート造建物の終局強度型耐震 設計指針・同解説, 1990

［11］加藤大介、芝譲、松田壮史：変動軸力を考慮した R C 柱の 変形能の評価法、日本建築学会構造系論文集、第506号、 pp.155-161, 1998.4

[12］佐々木潤一郎、加藤大介： R C 造柱のひび割れ幅, 圧壊領 域長さおよび軸力負担性能の評価法、第24回コンクリート 工学年次論文報告集 24-2、pp.253-258, 2002

［13］孫浩陽、佐々木潤一郎、東川敬子、加藤大介： R C 造異形 断面柱の変形能評価実験、第23回コンクリート工学年次論 文報告集23-3、pp.151-156, 2001

［14］ 日本建築学会：鉄筋コンクリート造建物の勒性保証型耐震 設計指針 · 同解説

[15] 菅野俊介：鉄筋コンクリート部材の復元力特性に関する研 究,コンクリートジャーナルVol.11,No.2,Feb., pp.1-9, 1973

[16] 平成4年度 New Rc 研究開発概要報告書 C-7) コンクアイド・コンクリトの力学特性に関する資料のとりまとめ、国土開発技術セン ター

（2002年 6 月 12 日原稿受理，2003年 1 月 23 日採用決定） 